\title{
Konsep dan Implementasi Good Governance pada Organisasi Sektor Publik
}

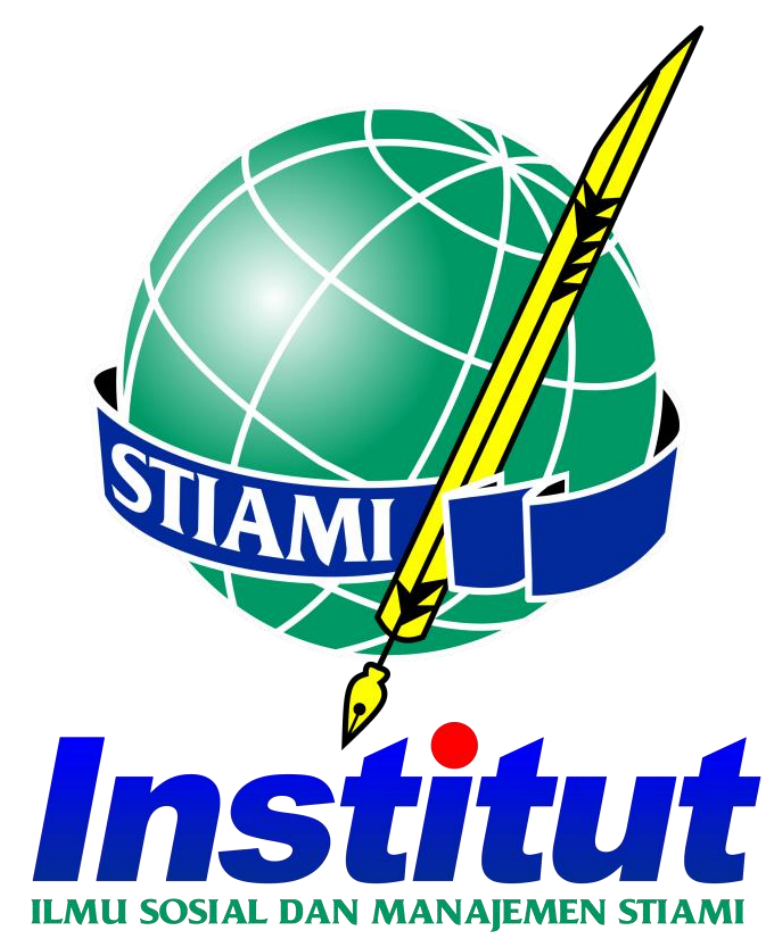

\author{
Oleh: \\ Kelompok X (Sepuluh) \\ Alfhi Fusvita Cahya (BC 191120263) \\ Wahyuni Sri Lestariningsih (BC 191120026) \\ Widya Chalid (BC 191120131) \\ MATA KULIAH ADMINISTRASI PUBLIK KONTEMPORER \\ DOSEN BAPAK Dr. Ir. A. H. RAHADIAN, M.Si \\ PROGRAM STUDI MAGISTER ADMINISTRASI PUBLIK \\ INSTITUT ILMU SOSIAL DAN MANAJEMEN STIAMI \\ TAHUN AKADEMIK 2019/2020
}




\section{KATA PENGANTAR}

Segala puji syukur kami panjatkan kehadirat Allah SWT yang telah memberikan rahmat serta karunia-Nya kepada kami sehingga dapat menyelesaikan makalah ini. Makalah ini dibuat untuk memenuhi tugas perkuliahan Administrasi Publik Kontemporer yang berjudul "Konsep dan Implementasi Good Governance pada Organisasi Sektor Publik", makalah ini membahas tentang informasi Good Governance dan mengkritisi perkembangannya di Indonesia.

Kami berharap dengan adanya makalah ini dapat memberikan pengetahuan lebih dan bermanfaat bagi para pembaca, kami menyadari dalam pembuatan makalah ini masih jauh dari kata sempurna sehingga kritik dan saran sangat kami harapkan dari para pembaca.

Akhir kata, kami sampaikan terima kasih kepada semua pihak yang membantu dalam penyusunan makalah ini sehingga makalah ini dapat terselesaikan. Semoga Allah SWT senantiasa meridhai kita semua. 


\begin{abstract}
ABSTRAK
Konsep adalah suatu arti yang mewakili sejumlah objek yang mempunyai ciriciri yang sama. Implementasi adalah suatu tindakan atau pelaksana rencana yang telah disusun secara cermat dan rinci (matang). Good governance adalah suatu penyelenggaraan manajemen pembangunan yang solid dan bertanggung jawab yang sejalan dengan prinsip demokrasi dan pasar yang efisien. Menurut Riswanda Imawan (2002:32) bahwa Good Governance diartikan suatu cara kekuasaan Negara yang difungsikan untuk mengatur sumber-sumber ekonomi dan sosial dengan tujuan pembangunan masyarakat.Sektor public adalah sektor yang menyediakan berbagai layanan pemerintah kepada masyarakat. Sehingga pada akhirnya kami mengangkat judul "Konsep dan implementasi good governance pada organisasi sektor public" yang terfokus pada sistem baru pemerintah berupa Online Single Submission (OSS). Karena dengan adanya sistem OSS mampu mempercepat pengurusan perizinan, dan memangkas banyak tahapan.
\end{abstract}

Kata Kunci: Konsep, Implementasi, Good Governance, Sektor publik 


\begin{abstract}
The concept is a meaning that represents a number of objects that have the same characteristics. Implementation is an action or implementing plan that has been prepared carefully and in detail (mature). Good governance is an implementation of solid and responsible development management that is in line with the principles of democracy and an efficient market. According to Riswanda Imawan (2002: 32) that Good Governance is defined as a way of state power that is functioned to regulate economic and social resources with the aim of community development. The public sector is a sector that provides various government services to the community. So in the end we raised the title "The concept and implementation of good governance in public sector organizations" which focused on the government's new system of Online Single Submission (OSS). Because with the OSS system is able to accelerate licensing, and cut many steps.
\end{abstract}

Keywords: Concept, Implementation, Good Governance, Public Sector 


\section{DAFTAR ISI}

KATA PENGANTAR

ABSTRAK

DAFTAR ISI

BAB I PENDAHULUAN

1. LATAR BELAKANG

2. RUANG LINGKUP PENULISAN...

3. TUJUAN DAN MANFAAT PENULISAN

BAB II PERMASALAHAN.

BAB III SOLUSI (PEMCAHAN MASALAH)

BAB IV PENUTUP (KESIMPULAN).

DAFTAR PUSTAKA. 


\section{BAB I}

\section{PENDAHULUAN}

\section{Latar Belakang}

Good governance yang diterjemahkan sebagai tata pemerintahan yang baik merupakan hal yang populer, baik di pemerintahan, civil society maupun di dunia swasta. Kepopulerannya adalah akibat semakin kompleksnya permasalahan, seolah menegaskan tidak adanya perubahan sistem kinerja pemerintahan yang baik di negeri ini. Di pemerintahan (public governance), tema ini begitu menyentuh. Banyak pihak yang menyatakan bahwa masalah mendasar bangsa ini akan terselesaikan kalau birokrasi pemerintahnya sudah kembali ke jalan yang baik. Karenanya bagi aparatur pemerintah, good governance adalah kewajiban yang harus diwujudkan. Keberhasilan penyelenggaraan tata pemerintahan yang baik sangat ditentukan oleh keterlibatan dan sinergi atas unsur- unsur dalam kepemerintahan yang dapat dikelompokan menjadi 3 kategori, yaitu:

1. Negara/Pemerintahan: konsepsi pemerintahan pada dasarnya adalah kegiatan kenegaraan, tetapi lebih jauh dari itu melibatkan pula sektor swasta dan kelembagaan masyarakat madani.

2. Sektor Swasta: pelaku sektor swasta mencakup perusahaan swasta yang aktif dalam interaksi dalam sistem pasar.

3. Masyarakat Madani: kelompok masyarakat dalam konteks kenegaraan pada dasarnya berada diantara atau di tengah-tengah antara pemerintah dan perseorangan, yang mencakup baik perseorangan maupun kelompok masyarakat yang berinteraksi secara sosial, politik, ekonomi

Dalam penyelenggaraan pemerintahan, aparatur pemerintah merupakan salah satu aktor penting yang memegang kendali proses berlangsungnya good governance. Keterlibatan aparatur pemerintah dalam mendukung keberhasilan penyelenggaraan pemerintahan sangat ditentukan antara lain oleh pemahaman terhadap konsep tata pemerintahan yang baik serta pengamalannya yang sangat terkait dengan birokrasi dan manajemen birokrasi pemerintah. 
Pola hubungan aparatur/birokrasi dengan kecenderungan sikap mereka terhadap "clients" atau masyarakat dan kelompok dapat dibedakan dalam dua kategori 2 yaitu: "service orientation" dan "social control orientation". Birokrasi dengan "service orientation" memberikan pelayanan dengan orang - orang yang berhubungan dengannya, dengan sikap pelayanan yang profesional yang bertujuan menjamin kepuasan pihak yang dilayani. Sedangkan birokrasi dengan "social control orientation" lebih menekankan pada pengendalian atau pengawasan karena ia menjalankan suatu peraturan guna memelihara ketertiban masyarakat. Aparatur merupakan suatu komunitas individu-individu yang memiliki tugas dan fungsi yang terlembagakan untuk melayani rakyat diartikan secara singkat sebagai pemikir, perencana, pelaksana sekaligus pengawas jalannya kegiatan pemerintahan, pembangunan dan pembinaan masyarakat atas nama kepala daerah (Sarundajang, 2002:164).

Dalam konteks pemerintahan yang baik, salah satu kunci sukses terpenting dari adanya perubahan dalam proses governance terletak pada individu-individu yang ada di dalam proses governance itu sendiri. Individuindividu adalah mereka yang menciptakan dan memelihara perubahan. Wilson dan Rosenfeld mengemukakan 4 (empat) alasan resistensi individu terhadap perubahan yaitu: kepentingan pribadi, rendahnya tingkat kepercayaan, perbedaan pandangan/penilaian, rendahnya toleransi terhadap perubahan. (Sumarto, 2004: 11) Aparatur yang baik adalah yang mampu memberi kepada masyarakat apa yang mereka butuhkan, bahkan sebelum masyarakat itu sendiri memintanya. Dalam keadaan seperti ini, hati nurani aparatur pemerintahan adalah hati nurani dari masyarakat itu sendiri. (Sarundajang, 2002: 164).

Untuk mencapai pemerintahan yang baik perlu adanya konsep Good Governance, diantaranya:

1. Tata pemerintahan yang berwawasan ke depan (visi strategis), Semua kegiatan pemerintah di berbagai bidang dan tingkatan seharusnya didasarkan pada visi dan misi yang jelas dan jangka waktu pencapaiannya serta dilengkapi strategi implementasi yang tepat sasaran, manfaat dan berkesinambungan. 
2. Tata pemerintahan yang bersifat terbuka (transparan), Wujud nyata prinsip tersebut antara lain dapat dilihat apabila masyarakat mempunyai kemudahan untuk mengetahui serta memperoleh data dan informasi tentang kebijakan, program, dan kegiatan aparatur pemerintah, baik yang dilaksanakan di tingkat pusat maupun daerah.

3. Tata pemerintahan yang mendorong partisipasi masyarakat, Masyarakat yang berkepentingan ikut serta dalam proses perumusan dan/atau pengambilan keputusan atas kebijakan publik yang diperuntukkan bagi masyarakat, sehingga keterlibatan masyarakat sangat diperlukan pada setiap pengambilan kebijakan yang menyangkut masyarakat luas.

4. Tata pemerintahan yang bertanggung jawab/ bertanggung gugat (akuntabel), Instansi pemerintah dan para aparaturnya harus dapat mempertanggungjawabkan pelaksanaan kewenangan yang diberikan sesuai dengan tugas pokok dan fungsinya. Demikian halnya dengan kebijakan, program, dan kegiatan yang dilakukannya dapat dipertanggungjawabkan.

5. Tata pemerintahan yang menjunjung supremasi hukum, Wujud nyata prinsip ini mencakup upaya penuntasan kasus KKN dan pelanggaran HAM, peningkatan kesadaran HAM, peningkatan kesadaran hukum, serta pengembangan budaya hukum. Upaya-upaya tersebut dilakukan dengan menggunakan aturan dan prosedur yang terbuka dan jelas, serta tidak tunduk pada manipulasi politik.

6. Tata pemerintahan yang demokratis dan berorientasi pada konsensus, Perumusan kebijakan pembangunan baik di pusat maupun daerah dilakukan melalui mekanisme demokrasi, dan tidak ditentukan sendiri oleh eksekutif. Keputusan-keputusan yang diambil antara lembaga eksekutif dan legislatif harus didasarkan pada konsensus agar setiap kebijakan publik yang diambil benar-benar merupakan keputusan bersama.

7. Tata pemerintahan yang berdasarkan profesionalitas dan kompetensi, Wujud nyata dari prinsip profesionalisme dan kompetensi dapat dilihat dari upaya penilaian kebutuhan dan evaluasi yang dilakukan terhadap tingkat kemampuan dan profesionalisme sumber daya manusia yang ada, dan dari upaya perbaikan atau peningkatan kualitas sumber daya manusia. 
8. Tata pemerintahan yang cepat tanggap (responsif), Aparat pemerintahan harus cepat tanggap terhadap perubahan situasi/kondisi mengakomodasi aspirasi masyarakat, serta mengambil prakarsa untuk mengatasi berbagai masalah yang dihadapi masyarakat.

9. Tata pemerintahan yang menggunakan struktur \& sumber daya secara efisien \& efektif, Pemerintah baik pusat maupun daerah dari waktu ke waktu harus selalu menilai dukungan struktur yang ada, melakukan perbaikan struktural sesuai dengan tuntutan perubahan seperti menyusun kembali struktur kelembagaan secara keseluruhan, menyusun jabatan dan fungsi yang lebih tepat, serta selalu berupaya mencapai hasil yang optimal dengan memanfaatkan dana dan sumber daya lainnya yang tersedia secara efisien dan efektif.

10. Tata pemerintahan yang terdesentralisasi, pendelegasian tugas dan kewenangan pusat kepada semua tingkatan aparat sehingga dapat mempercepat proses pengambilan keputusan, serta memberikan keleluasaan yang cukup untuk mengelola pelayanan publik dan menyukseskan pembangunan di pusat maupun di daerah.

11. Tata pemerintahan yang mendorong kemitraan dengan dunia usaha swasta dan masyarakat, pembangunan masyarakat madani melalui peningkatan peran serta masyarakat dan sektor swasta harus diberdayakan melalui pembentukan kerjasama atau kemitraan antara pemerintah, swasta, dan masyarakat. Hambatan birokrasi yang menjadi rintangan terbentuknya kemitraan yang setara harus segera diatasi dengan perbaikan sistem pelayanan kepada masyarakat dan sektor swasta serta penyelenggaraan pelayanan terpadu.

12. Tata pemerintahan yang memiliki komitmen pada pengurangan kesenjangan, Pengurangan kesenjangan dalam berbagai bidang baik antara pusat dan daerah maupun antardaerah secara adil dan proporsional merupakan wujud nyata prinsip pengurangan kesenjangan. Hal ini juga mencakup upaya menciptakan kesetaraan dalam hukum (equity of the law) serta mereduksi berbagai perlakuan diskriminatif yang menciptakan kesenjangan antara laki-laki dan perempuan dalam kehidupan bermasyarakat. 
13. Tata pemerintahan yang memiliki komitmen pada lingkungan hidup, Daya dukung lingkungan semakin menurun akibat pemanfaatan yang tidak terkendali. Kewajiban penyusunan analisis mengenai dampak lingkungan secara konsekuen, penegakan hukum lingkungan secara konsisten, pengaktifan lembaga-lembaga pengendali dampak lingkungan, serta pengelolaan sumber daya alam secara lestari merupakan contoh perwujudan komitmen pada lingkungan hidup.

Dengan adanya konsep good governance tersebut diatas, diharapkan aparatur pemerintah mampu mengubah posisi dan peran dalam memberikan pelayanan publik yaitu:

1. Dari yang suka mengatur dan memerintah berubah menjadi suka melayani;

2. Dari yang suka menggunakan pendekatan kekuasaan berubah menjadi suka menolong menuju ke arah yang fleksibel, kolaboratif dan dialogis;

3. Dari cara-cara yang sloganis menuju cara-cara kerja yang realistis pragmatis.

Secara mendasar perubahan sikap aparatur pemerintah sebagai pelayan masyarakat sangat terkait dengan program-program penyempurnaan pendayagunaan aparatur pemerintah daerah. Pemerintah Daerah merupakan organisasi pelayanan masyarakat. Dengan demikian harus memberikan citra yang baik dengan kinerja yang baik pula. Secara umum, aparatur merupakan perangkat pemerintah yang memiliki sistem aturan dan terstruktur, yang digunakan untuk menyelenggarakan pemerintahan baik di tingkat Pusat atau Daerah (Widodo, 2001: 32).

Jadi aparatur pemerintah merupakan pengatur sekaligus pelayan masyarakat yang memberikan pelayanan secara profesional, jujur, adil dan merata, bekerja secara efektif, efisien dan ekonomis dalam rangka penyelenggaraan tugas negara untuk mencapai tujuan negara yang secara kontekstual juga ikut bertanggung jawab terhadap kesejahteraan dan kepuasan masyarakat sebagai pihak yang dilayani (provider) (Sumarto, 2004: 11).

Maka dari itu ketika aparatur telah memiliki pemahaman yang komprehensif dan dia memegang teguh prinsip-prinsip good governance secara konsisten maka akan terwujud pemerintahan yang baik dan bersih, 
sehingga mereka mampu bekerja dalam "super-tim" (kekuatan tim kerja) bukan "super-man" (kekuatan individu) karena sebagai negara yang sedang berkembang aparatur pemerintah di Pemerintah Daerah di Indonesia menganggap dirinya sebagai "yang serba tahu". Stereotip ini muncul ketika masyarakat akan mengurus perizinan misalnya, mereka tidak punya pilihan selain membuatnya di kantor pemerintah birokrasi merupakan suatu organisasi pemerintahan yang terdiri dari sub-sub struktur yang memiliki hubungan satu dengan yang lain, yang memiliki fungsi, peran, dan kewenangan dalam melaksanakan pemerintahan, dalam rangka mencapai suatu visi, misi, tujuan, dan program yang telah ditetapkan.

Fungsi dan peran birokrasi meliputi hal-hal sebagai berikut:

(1) melaksanakan pelayanan publik;

(2) pelaksana pembangunan yang profesional (merrit system);

(3) perencana, pelaksanan, dan pengawas kebijakan (manajemen pemerintahan);

(4) alat pemerintah untuk melayani kepentingan (abdi) masyarakat dan negara yang netral dan bukan merupakan bagian dari kekuatan atau mesin politik (netralitas birokrasi).

Membangun birokrasi yang benar-benar memiliki ciri-ciri good governance sampai saat ini sepertinya masih jauh dari harapan. Hal ini dikarenakan birokrasi yang demikian haruslah birokrasi yang memiliki legitimasi, akuntabilitas dalam kebebasan pers, pembuatan keputusan yang transparan, mekanisme pertanggungjawaban pemerintah yang jelas, serta memiliki kompetensi untuk membuat dan melaksanakan kebijakan, penghormatan pemerintah pada HAM dan rule of law (perlindungan atas hak individu dan kelompok, kerangka kegiatan ekonomi dan sosial, serta partisipasi publik).

Birokrasi yang ideal adalah birokrasi yang mampu memelihara dan meningkatkan kinerja produktif sehingga dapat memberikan pelayanan terbaik bagi masyarakat. Langkah konkret dan utama yang dibutuhkan itu, menurutnya, adalah mendorong semangat kerja di lingkungan birokrasi dan meningkatkan kapasitas aparatur birokrasi agar memiliki pengetahuan manajemen pemerintahan yang memadai serta memiliki performance yang andal, karena dalam keseharian saat ini birokrasi cenderung dipersepsikan 
dalam makna yang kurang bagus karena identik dengan prosedur yang berbelit-belit, tidak efisien, lamban, menghambat, mengisap, korupsi, dan sebagainya. Struktur dan orientasi birokrasi demikian merupakan implikasi dari penerapan prinsip-prinsip model birokrasi rasional versi Max Weber. 6 Implementasi Otonomi Daerah diasumsikan oleh berbagai pihak akan membawa suatu perubahan yang sangat signifikan terhadap pola manajemen pemerintahan dalam pelaksanaan fungsi-fungsi utama pemerintahan yaitu pembangunan, pelayanan dan pemberdayaan masyarakat.

Pergeseran wewenang pemerintahan dari Pusat ke Daerah memberikan dampak yang sangat luas dalam segala aspek kehidupan. Berlakunya Undang-Undang Nomor 32 Tahun 2004 tentang Pemerintahan Daerah diharapkan memberikan dampak yang nyata terhadap peningkatan pelayanan terhadap masyarakat. Pelimpahan wewenang dari Pusat ke Daerah memungkinkan terjadinya penyelenggaraan pelayanan umum dengan jalur birokrasi yang lebih ringkas dan membuka peluang Pemerintah daerah untuk mampu berpikir inovatif yang berdasarkan pada efisiensi dan efektifitas, akuntabilitas, transparansi dan pelibatan masyarakat di dalam pengambilan setiap kebijakan daerah yang semuanya bertujuan untuk mewujudkan tata pemerintahan yang baik (good governance).

Keberhasilan penyelenggaraan otonomi daerah sangat tergantung pada kemampuan keuangan daerah (PAD), sumber daya yang dimiliki daerah, serta kemampuan daerah untuk mampu mengoptimalisasikan potensi yang ada. Kebijakan untuk mewujudkan birokrasi yang netral dalam penyelenggaraan administrasi dan pemerintahan negara, ternyata dalam praktiknya banyak menghadapi rintangan. Padahal di tengah rintangan itu, masyarakat sangat merindukan pelayanan publik yang baik, dalam arti proporsional dengan kepentingan (kebutuhan), yaitu birokrasi yang berorientasi kepada penciptaan keseimbangan antara kekuasaan (power) yang dimiliki dengan tanggung jawab (accountability) yang mesti diberikan kepada masyarakat yang dilayani. Setiap daerah memiliki keunikan sendirisendiri, baik dari segi kependudukan maupun dari geografisnya.

Akibat dari hal itu maka pemberian otonomi daerah juga akan berbeda antara daerah yang satu dengan daerah yang lainnya, disesuaikan dengan kebutuhan. Kelemahan dalam mencetak aparatur yang handal dan 
profesional beberapa tahun belakangan ini mengakibatkan semakin banyaknya protes dari masyarakat dan hal itu merupakan indikator dari gagalnya pelayanan yang diberikan pemerintah kepada masyarakat. Pemerintahan daerah baru hasil pilihan langsung rakyat punya peluang membangun tradisi pelayanan publik yang ideal. Melalui mekanisme good governance dalam era informasi yang bersendikan demokratisasi dituntut untuk mampu menggalang partisipasi, mengedepankan transparansi dan akuntabilitas dalam menyelenggarakan pelayanan umum dalam rangka mensejahterakan masyarakatnya.

Oleh karena itu, dalam hal ini akan terlihat esensi dari good governance sebagai salah satu proses sektor publik, swasta dan masyarakat untuk menangani persoalan-persoalan publik. Hingga pada akhirnya pemerintah mengeluarkan Peraturan Pemerintah Nomor 24 Tahun 2018 tentang Pelayanan Perizinan Berusaha Terintigrasi Secara Elektronik. Hal itu guna mempermudah dalam melakukan pengurusan perizinan, sehingga bisa dilakukan secara satu pintu dan dapat dikerjakan dimana saja. Namun hal tersebut memiliki plus dan minus untuk pemerintah pusat dan pemerintah daerah, karena dengan adanya Peraturan Pemerintah tersebut jelas sangat memudahkan swasta, civil society, namun membuat pemerintah daerah tidak berfungsi maksimal, karena seluruh izin terintegrasi dalam satu sistem yang disebut dengan sistem Online Single Submission (OSS) yang mulai diberlakukan 21 Juni 2018. Dalam rangka percepatan dan peningkatan penanaman modal dan berusaha, pemerintah memandang perlu menerapkan pelayanan Perizinan Berusaha terintegrasi secara elektronik.

Atas dasar pertimbangan tersebut, pada 21 Juni 2018, Presiden Joko Widodo telah menandatangani Peraturan Pemerintah Nomor 24 tentang Pelayanan Perizinan Berusaha Terintegrasi Secara Elektronik. Ditegaskan dalam PP ini, jenis Perizinan Berusaha terdiri atas:

a. Izin Usaha; dan

b. Izin Komersial atau Operasional

Sementara pemohon Perizinan Berusaha terdiri atas:

a. Pelaku Usaha perseorangan; dan

b. Pelaku Usaha non perseorangan. 
Perizinan Berusaha, menurut Peraturan Pemerintah ini, diterbitkan oleh menteri, pimpinan lembaga, gubernur, atau bupati/walikota sesuai kewenangannya, termasuk Perizinan Berusaha yang kewenangan penerbitannya telah dilimpahkan atau didelegasikan kepada pejabat lainnya. "Pelaksanaan kewenangan penerbitan Perizinan Berusaha sebagaimana dimaksud, termasuk penerbitan dokuman lain yang berkaitan dengan Perizinan Berusaha wajib dilakukan melalui Lembaga OSS," bunyi Pasal 19 Peraturan Pemerintah ini. Lembaga OSS berdasarkan ketentuan Peraturan Pemerintah ini, untuk dan atas nama menteri, pimpinan lembaga, gubernur, atau bupati/wali kota menerbitkan Perizinan Berusaha sebagaimana dimaksud, dalam bentuk Dokumen Elektronik sesuai dengan ketentuan peraturan perundang-undangan di bidang informasi dan transaksi elektronik. Dokumen Elektronik sebagaimana dimaksud disertai dengan Tanda Tangan Elektronik, yang berlaku sah dan mengikat berdasarkan hukum serta merupakan alat bukti yang sesuai dengan ketentuan peraturan perundangundangan, dan dapat dicetak (print out).

Pelaksanaan perizinan berusaha menurut Peraturan Pemerintah ini, Pelaku Usaha melakukan Pendaftaran untuk kegiatan berusaha dengan cara mengakses laman OSS. Dalam hal Pelaku Usaha merupakan perseorangan pendaftaran dilakukan dengan cara memasukkan NIK (Nomor Induk Kependudukan), nomor pengesahan akta pendirian atau nomor pendaftaran PT, yayasan/badan usaha yang didirikan oleh yayasan, koperasi, persekutuan komenditer, persekutuan firma, persekutuan perdata, dasar hukum pembentukan perusahaan umum, perusahaan umum daerah, badan hukum lainnya yang dimiliki oleh negara, lembaga penyiaran publik, atau badan layanan umum.

Selanjutnya, setelah mendapatkan akses dalam laman OSS mengisi data yang ditentukan. "Dalam hal Pelaku Usaha yang melakukan Pendaftaran sebagaimana dimaksud belum memiliki NPWP. OSS memproses pemberian NPWP," bunyi Pasal 23 Peraturan Pemerintah ini.

Selanjutnya, Lembaga OSS menerbitkan NIB (Nomor Induk Berusaha) setelah Pelaku Usaha melakukan Pendaftaran melalui pengisian data secara lengkap dan mendapatkan NPWP. NIB berbentuk 13 (tiga belas) digit angka acak yang diberi pengaman dan disertai dengan Tanda Tangan Elektronik. 
Menurut Peraturan Pemerintah ini, NIB merupakan identitas berusaha dan digunakan oleh Pelaku Usaha untuk mendapatkan Izin Usaha dan Izin Komersial atau Operasional, termasuk untuk pemenuhan persyaratan Izin Usaha dan Izin Komersial atau Operasional.

NIB sebagaimana dimaksud berlaku juga sebagai:

1. Tanda Daftar Perusahaan (TDP) sebagaimana dimaksud dalam peraturan perundang-undangan di bidang tanda daftar perusahaan

2. Angka Pengenal Impor (API) sebagaimana dimaksud dalam peraturan perundang-undangan di bidang perdagangan dan

3. Hak akses kepabeanan sebagaimana dimaksud dalam peraturan perundang undangan di bidang kepabeanan.

Ditegaskan dalam Peraturan Pemerintah ini, Pelaku Usaha yang telah mendapatkan NIB sekaligus terdaftar sebagai peserta jaminan sosial kesehatan dan jaminan sosial ketenagakerjaan.

Dalam hal Pelaku Usaha akan mempekerjakan tenaga kerja asing, menurut Peraturan Pemerintah ini, Pelaku Usaha mengajukan pengesahan Rencana Penggunaan Tenaga Kerja Asing (RPTKA), dengan mengisi data pada laman OSS. Selanjutnya sistem OSS memproses pengesahan RPTKA sesuai dengan ketentuan peraturan perundang-undangan, dan pengesahan RPTKA itu merupakan izin mempekerjakan tenaga kerja asing.

Ditegaskan dalam Peraturan Pemerintah ini, Izin Usaha wajib dimiliki oleh Pelaku Usaha yang telah mendapatkan NIB, dan Lembaga OSS menerbitkan Izin Usaha berdasarkan Komitmen kepada:

1. Pelaku Usaha yang tidak memerlukan prasarana untuk menjalankan usaha dan/atau kegiatan dan

2. Pelaku Usaha yang memerlukan prasarana untuk menjalankan usaha dan/atau kegiatan dan telah memiliki atau menguasai prasarana sebagaimana dimaksud.

Lembaga OSS menerbitkan Izin Usaha berdasarkan Komitmen kepada Pelaku Usaha yang memerlukan prasarana untuk menjalankan usaha dan/atau kegiatan tapi belum memiliki atau menguasai prasarana setelah Lembaga OSS menerbitkan:
a. Izin Lokasi
b. Izin Lokasi Perairan 

c. Izin Lingkungan dan/atau
d. IMB.

Pelaku Usaha yang telah mendapatkan Izin Usaha sebagaimana dimaksud, menurut Peraturan Pemerintah ini, dapat melakukan kegiatan:
a. pengadaan tanah
b. perubahan luas lahan
c. pembangunan bangunan gedung dan pengoperasiannya
d. pengadaan peralatan atau sarana
e. pengadaan sumber daya manusia
f. penyelesaian sertifikasi atau kelaikan
g. pelayanan uji coba produksi dan/atau
h. pelaksanaan produksi.

Sementara Pelaku Usaha yang telah mendapatkan Izin Usaha namun belum menyelesaikan:

a. Amdal dan/atau

b. rencana teknis bangunan gedung, menurut Peraturan Pemerintah ini, belum dapat melakukan kegiatan pembangunan bangunan gedung.

Dalam Peraturan Pemerintah ini disebutkan, Lembaga OSS menerbitkan Izin Komersial atau Operasional berdasarkan Komitmen untuk memenuhi:

a. standar, sertifikat, dan/atau lisensi dan/atau

b. pendaftaran barang/jasa sesuai dengan jenis produk dan/atau jasa yang dikomersialkan oleh Pelaku Usah melalui sistem OSS.

"Lembaga OSS membatalkan Izin Usaha yang sudah diterbitkan dalam hal Pelaku Usaha tidak menyelesaikan pemenuhan Komitmen dan/atau Izin Komersial atau Operasional," sebagaimana dimaksud dalam Pasal 40 Peraturan Pemerintah ini.

Ditegaskan dalam Peraturan Pemerintah ini, Izin Usaha dan/atau Izin Komersial atau Operasional berlaku efektif setelah Pelaku Usaha menyelesaikan Komitmen dan melakukan pembayaran biaya Perizinan Berusaha sesuai dengan ketentuan peraturan perundang-undangan.

Pemenuhan Komitmen yang diatur dalam Peraturan Pemerintah ini meliputi Izin Lokasi, Izin Lokasi Perairan, Izin Lingkungan, dan/atau Izin Mendirikan Bangunan. 
Lembaga OSS menegaskan dalam Peraturan Pemerintah ini, bahwa Lembaga OSS berwenang untuk:

a. menerbitkan Perizinan Berusaha melalui sistem OSS

b. menetapkan kebijakan pelaksanaan Perizinan Berusaha melalui sistem OSS

c. menetapkan petunjuk pelaksanaan penerbitan Perizinan Berusaha pada sistem OSS

d. Mengelola dan mengembangkan sistem OSS, dan

e. Bekerja sama dengan pihak lain dalam pelaksanaan, pengelolaan, dan pengembangan sistem OSS.

"Pelaksanaan kewenangan dilakukan dengan berkoordinasi dengan menteri, pimpinan lembaga, gubernur, dan/atau bupati/wali kota, difasilitasi oleh menteri koordinator yang menyelenggarakan urusan pemerintahan di bidang perekonomian," sebagaiman dimaksud dalam Pasal 94 ayat $(2,3)$ Peraturan Pemerintah ini.

Dalam ketentuan peralihan disebutkan, Perizinan Berusaha yang telah diajukan oleh Pelaku Usaha sebelum berlakunya Peraturan Pemerintah ini, diproses melalui sistem OSS.

\section{Ruang Lingkup Penulisan}

Adapun ruang lingkup yang akan dibahas dalam penulisan makalah "Konsep dan Implementasi Good Governance pada Organisasi Sektor Publik" dibatasi antara lain:

a. Bagaimana cara mudah dalam pengurusan perizinan yang singkat dan cepat bagi organisasi sektor publik baik swasta dan civil society?

b. Bagaimana cara mengakses link oss.go.id untuk mempermudah proses pengerjaan perizinan bagi swasta dan civil society?

c. Apakah Pelayanan Terpadu Satu Pintu, memudahkan swasta dan civil society dalam pengerjaan izin apapun dari kementerian manapun yang berkaitan?

d. Apa kekurangan dari aplikasi oss.go.id sehingga masih banyak sektor organisasi publik baik swasta dan civil society yang salah dalam pengisian dan berakibat terhambatnya perizinan tersebut keluar? 
e. Mengapa pemerintah daerah kesulitan dalam mensosialisasikan dan memaparkan sistem OSS yang sudah berlaku kepada organisasi sektor publik baik swasta dan civil society?

\section{Tujuan dan Manfaat Penulisan}

Tujuan dari penulisan makalah ini diantaranya adalah:

a. Agar organisasi sektor publik baik swasta dan civil society mengetahui bahwa saat ini pengurusan perizinan sudah lebih singkat dan lebih mudah.

b. Agar organisasi sektor publik baik swasta dan civil society mengetahui bahwa untuk pengurusan perizinan dapat dilakukan dimana saja dengan membuka link oss.go.id.

c. Agar organisasi sektor publik baik swasta dan civil society bisa dengan cepat mengakses perizinan melalui pelayanan terpadu satu pintu (PTSP).

Manfaat dari penulisan makalah ini diantaranya adalah:

a. Memudahkan organisasi sektor publik baik swasta dan civil society dalam pengurusan perizinan yang singkat dan cepat.

b. Memudahkan organisasi sektor publik baik proses pengerjaan perizinan yang dapat dilakukan dimana saja dan kapan saja bagi swasta dan civil society dengan mengakses link oss.go.id.

c. Dengan adanya Pelayanan Terpadu Satu Pintu, memudahkan swasta dan civil society dalam pengerjaan izin apapun dari kementerian manapun yang berkaitan. 


\section{BAB II}

\section{PERMASALAHAN}

Good governance pada dasarnya adalah suatu konsep yang mengacu kepada proses pencapaian keputusan dan pelaksanaannya yang dapat dipertanggungjawabkan secara bersama. Sejalan dengan prinsip demokrasi yang lebih efesian pencengahan korupsi baik secara politik maupun administrasi.

Hambatan dalam mewujudkan good governance atau melaksanakan pemerintahan yang baik yang berbasis pada pengelolaan sistem keuangan daerah yang baik, masih banyak menemui kendala. Berbagai kendala dalam pengelolaan keuangan daerah dapat terjadi baik dalam penentuan kebijakan makro maupun teknis operasionalnya.

Untuk itu, perlu dilakukan reformasi administrasi publik khususnya dibidang manajemen sektor publik agar terjadi efektivitas dan transparansi manajemen yang berimbas pada perbaikan pelayanan kepada publik. Dalam hal lain ada beberapa hambatan yang menjadi kendala mewujudkan antara lain :

1. Integritas Pelaku Pemerintahan Peran pemerintah yang sangat berpengaruh,maka integritas dari para pelaku pemerintahan cukup tinggi tidak akan terpengaruh walaupun ada kesempatan untuk melakukan penyimpangan misalnya korupsi yang udah menyebar dimana2.

2. Kondisi Politik dalam negeri yang dianggap sepele apalagi setiap hambatan dan masalah yang dihadirkan oleh politik. Bagi terwujudnya good governance konsep politik yang tidak/kurang demokratis pada berbagai persoalan di lapangan. Maka tentu harus segera dilakukan perbaikan.

3. Kondisi Ekonomi Masyarakat Krisis ekonomi bisa melahirkan berbagai masalah sosial yang bila tidak teratasi akan mengganggu kinerja pemerintahan secara menyeluruh.

4. Kondisi Sosial Masyarakat yang solid dan berkemungkinan good governance bisa ditegakkan. yang harus ada pengawasan lebih kepada masyarakat 
5. Sistem Hukum Menjadi bagian yang tidak terpisahkan disetiap penyelenggaraan negara. Hukum faktor penting dalam penegakan good governance. Kelemahan sistem hukum yang akan berpengaruh besar terhadap kinerja pemerintahan secara keseluruhan.

Secara garis besar, permasalahan penerapan Good Governance meliputi:

1. Reformasi birokrasi belum berjalan sesuai dengan tuntutan masyarakat;

2. Tingginya kompleksitas permasalahan dalam mencari solusi perbaikan;

3. Masih tingginya tingkat penyalahgunaan wewenang, banyaknya praktek KKN, dan masih lemahnya pengawasan terhadap kinerja aparatur;

4. Makin meningkatnya tuntutan akan partisipasi masyarakat dalam kebijakan publik;

5. Meningkatnya tuntutan penerapan prinsip-prinsip tata kepemerintahan yang baik antara lain transparansi, akuntabilitas dan kualitas kinerja publik serta taat pada hukum;

6. Meningkatnya tuntutan dalam pelimpahan tanggung jawab, kewenangan dan pengambilan keputusan dalam era desentralisasi;

7. Rendahnya kinerja sumberdaya manusia dan kelembagaan aparatur; sistem kelembagaan (organisasi) dan ketatalaksanaan (manajemen) pemerintahan daerah yang belum memadai.

Adapun permasalahan yang kami angkat dalam makalah yang berjudul "Konsep dan Implementasi Good Governance pada Organisasi Sektor Publik" antara lain:

1. Apa kekurangan dari aplikasi oss.go.id sehingga masih banyak sektor organisasi publik baik swasta dan civil society yang salah dalam pengisian dan berakibat terhambatnya perizinan tersebut keluar?

2. Mengapa pemerintah daerah kesulitan dalam mensosialisasikan dan memaparkan sistem OSS yang sudah berlaku kepada organisasi sektor publik baik swasta dan civil society? 


\section{BAB III}

\section{SOLUSI (PEMECAHAN MASALAH)}

Terhadap permasalahan sebagaimana tersebut pada BAB II, maka kami akan membahasnya satu persatu terhadap permasalahan tersebut:

1. Apa kekurangan dari aplikasi oss.go.id sehingga masih banyak organisasi sektor publik baik swasta dan civil society yang salah dalam pengisian dan berakibat terhambatnya perizinan tersebut keluar?

Kekurangan pada aplikasi oss.go.id sebetulnya tidak ada, namun kurangnya sosialisasi membuat oragnisasi sektor publik terkhusus swasta dan civil society kesulitan dalam pengisian dan proses setiap langkahnya untuk mendapatkan izin yang diperlukan melalui oss.go.id.

Pada saat ini semua jenis usaha apapun memerlukan atau dituntut harus memiliki Nomor Induk Berusaha (NIB) dan untuk mendapatkan Nomor Induk Berusaha tersebut harus mendaftarakan diri dan memiliki akun untuk log in pada oss.go.id, untuk memiliki akun tersebut harus melakukan pendaftaran dengan memasukan Nomor Induk Kependudukan (NIK), dalam waktu 24 jam kerja, pihak yang mendaftar akan mendapatkan user name dan password melalui email yang didaftarkan, sehingga bisa log in dan memulai untuk mengajukan izin agar mendapatkan Nomor Induk Berusaha (NIB).

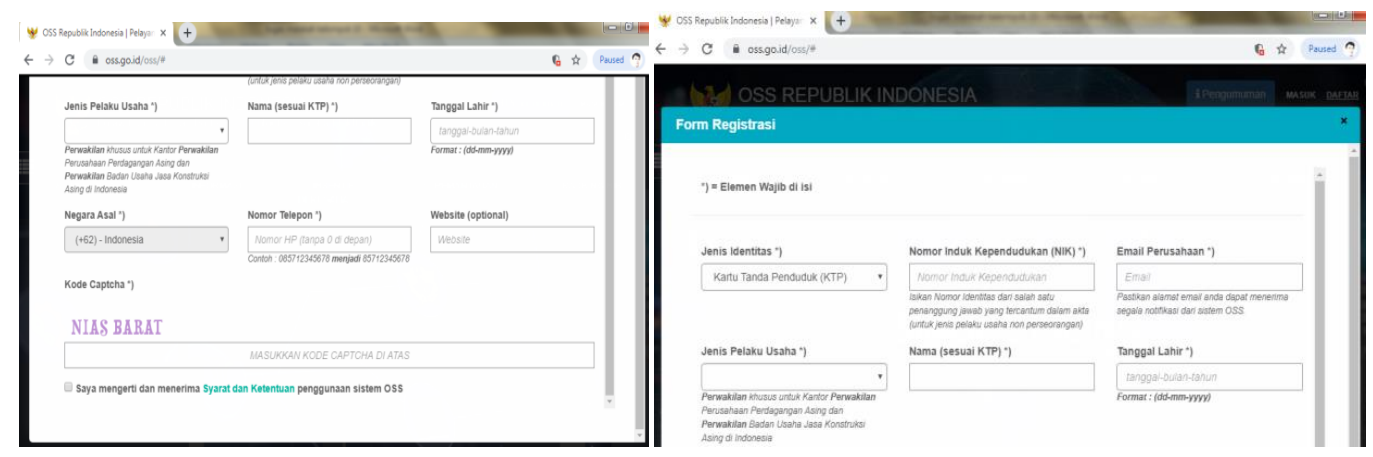

Form pengisian untuk mendapatkan username dan password log in oss.go.id

Langkah selajutnya melakukan pendafatran dengan memilih dua bagian yaitu izin perseorangan atau izin non perseorangan, pada bagian ini masih 
banyak swasta atau civil society yang kesulitan untuk menentukan pilihan, karena mereka belum mengetahui fungsi dari kedua pilihan tersebut, yang dimana izin perseorangan digunakan untuk mereka yang memiliki Badan usaha seperti PT, CV, yayasan, koperasi dan lain sebagaianya, sedangkan untuk izin non perseorangan diperuntukan untuk usaha yang belum memiliki badan hukum atau NPWP usaha.

Sebagai contoh kasus, kami mengambil dari salah satu perusahaan yang kesulitan untuk menentukan harus menggunakan izin perseorangan atau non perseorangn untuk mendapatkan NIB, sehingga perusahaan tersebut mendaftar di kedua pilihan yang ada, yaitu pada izin perseorangan dan pada izin non perseorangan, sehingga perusahaan tersebut memiliki dua NIB yaitu atas nama pribadi dan atas nama PT, dan data atas nama pribadi yang tertera pada izin perseorangan tidak dapat dihapus karena harus melakukan pengajuan non aktivasi pada web oss.go.id terlebih dahulu.

Masih banyak sekali organisasi sektor publik yang kesulitan dalam melengkapi data sehingga izin yang diperlukan terhambat dan sulit untuk selesai, hal tersebut dikarenakan kurangnya sosialisasi dari PTSP setempat.

Pada saat ini, semua izin termasuk BPJS ketenagakerjaan dan BPJS kesehatan sudah secara otomatis berada pada akun OSS yang dimiliki swasta atau civil society yang telah memiliki Nomor Induk Berusaha (NIB), sehingga perusahaan yang belum mendaftarakan BPJS akan terlacak oleh sistem OSS dengan sendirinya. Begitupun dengan pelaporan pajak, suatu perusahaan tidak dapat dikeluarkan Nomor Induk Berusahanya (NIB) jika dua tahun kebelakang belum melakukan pelaporan pajak. Jelas sistem ini membuat swasta dan civil society dispilin dalam segala hal, dan membuat segala perizinan menjadi lebih tertata dan rapi serta transparan, namun kekurangannya masih sangat minim sekali sosialisasi yang saat ini sistem oss sudah berjalan lebih dari satu tahun semenjak di tetapkan pada 1 juni 2018.

Contoh kasus lainnya, ada beberapa izin yang dikeluarkan melalui oss namun belum dinyatakan efektif dikarenakan harus dipenuhinya izin yang ada didaerah, contohnya yaitu izin lingkungan dikeluarkan oleh OSS, namun belum 
dapat dikatakan efektif jika swasta atau civil society tersebut belum mengurus UKL dan UPL pada dinas lingkungan hidup setempat, sehingga oss memberikan waktu untuk melengkapi syarat tersebut dan jika pada waktu yang telah ditentukan tidak dapat tepenuhi maka izin tersebut yang sudah di dapatkan secara otomatis akan dibekukan dan harus dilakukan pengajuan kembali melalui akun oss.go.id.

Selanjutnya, banyak organisasi sektor publik terkhusus swasta dan civil society belum memahami apa saja yang harus dimiliki setalah mendapatkan akses dalam laman oss.go.id, masih banyak yang belum mengetahui bahwa swasta atau civil society harus memiki:

a. Pendaftaran

$\checkmark$ Nomor Induk Berusaha (checklist hijau)

$\checkmark$ Izin Lokasi (checklist hijau)

b. Komitmen pemenuhan persyaratan perizinan prasarana usaha

c. Perizinan usaha

$\checkmark$ Izin Usaha Industri (checklist hijau)

d. Fasilitas

Sebagian dari swasta atau civil society belum mengetahui informasi bertanda checklist hijau merupakan perizinan yang telah diterbitkan, checklist merah merupakan perizinan yang harus diselesaikan dan/atau komitmen yang harus dipenuhi dalam jangka waktu tertentu, serta checklist biru merupakan fasilitas yang berhak didapatkan berdasarkan kriteria dan persyaratan sesuai peraturan perundang-undangan.

Berdasarkan Peraturan Pemerintah Nomor 24 Tahun 2018 tentang Pelayanan Perizinan Berusaha Terintegrasi secara Elektronik, apabila komitmen kepatuhan sebagaimana tercantum pada butir b dan c tidak dipenuhi sampai batas waktu yang ditentukan, maka kepada perusahaan tersebut dapat diberikan sanksi berupa pembekuan Nomor Induk Berusaha (NIB) yang telah diterbitkan sampai dengan pencabutan izin usaha. 


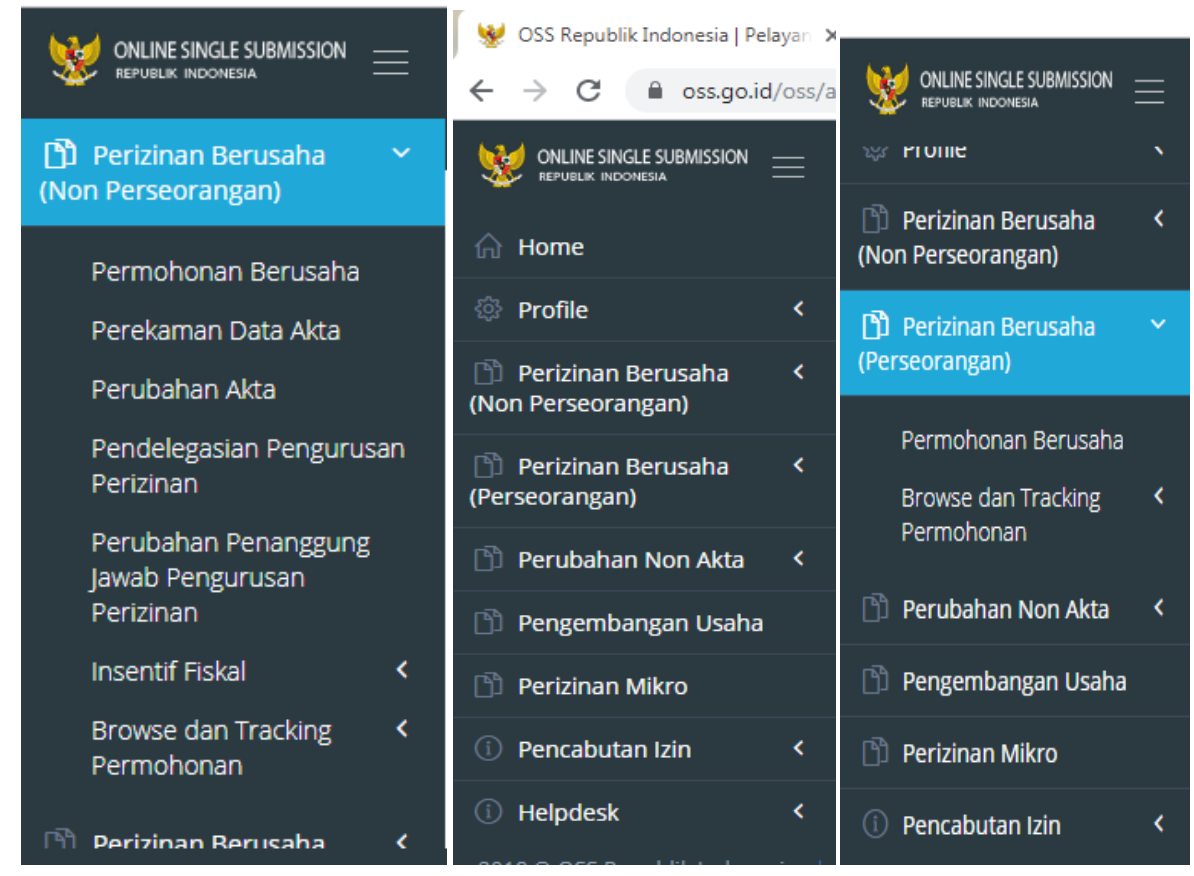

Menu pada akun Pilihan menu non perseorangan Pilihan menu perseorangan

Dengan adanya sistem OSS mebuat transparansi dalam segala hal, baik dalam pengurusan periznan, pemungutan retsibusi, dan lain sebagainya.

\section{Mengapa pemerintah daerah kesulitan dalam mensosialisasikan dan} memaparkan sistem OSS yang sudah berlaku kepada organisasi sektor publik baik swasta dan civil society?

Seperti kasus yang pernah kami temukan, masih banyak pemerintah daerah yang belum mengetahui adanya sistem baru yang disebut dengan oss.go.id, dan belum mampu mengoperasikan dengan baik sistem oss.go.id yang sudah berlaku sejak 01 Juni 2018, dimana saat ini Tanda Daftar Perusahaan (TDP) telah digantikan dengan Nomor Izin Berusaha (NIB), hingga saat ini sudah 1 tahun berjalan, masih ada beberapa daerah yang mengeluarkan TDP di daerahnya, hal tersebut karena minimnya informasi dan sosialisasi dari pemerintah pusat.

Selanjutnya dengan kurang cakapnya pemerintah daerah dalam mengoperasikan sistem oss.go.id menghambat organisasi sektor publik baik swasta maupun civil society untuk bisa dengan cepat mendapatkan izin yang diperlukan.

Sebagai contoh, di daerah Gresik dan Sukabumi masih banyak swasta atau civil society atau pelaku usaha yang belum mengetahui perlu memiliki 
Nomor Induk Berusaha (NIB) yang pada dasarnya dapat dimiliki dengan mudah dan dengan waktu yang singkat yang dapat dikerjakan kapan saja dan dimana saja. hal itu karena kurangnya sosialisasi dan belum diberlakukan sepenuhnya oleh pemerintah daerah. 


\section{BAB IV \\ PENUTUP}

\section{A. KESIMPULAN}

Dari dua permasalahan yang diangkat pada makalah ini, dapat kami simpulkan bahwa:

1. Dengan adanya sistem terpusat satu pintu melalui sistem yang dinamai oss.go.id sangat memudahkan para pelaku usaha untuk mendapatkan izin yang diperlukan sesuai kebutuhan tanpa harus berbelit belit dan memakan banyak waktu, karena hanya dengan cukup satu akses, dan satu dokumen yang dinamakan Nomor Induk Berusaha (NIB) para swasta, civil society, atau pelaku usaha dapat mengakses seluruh perizininan dengan mudah.

2. Namun hingga saat ini kurangnya sosialisasi dari pemerintah pusat maupun daerah mengakibatkan sulitnya para swasta, civil society, atau pelaku usaha untuk mendapatkan Nomor Induk Berusaha yang sebetulnya jika di sosialisasikan secara merata akan sangat mudah untuk bisa didapatkan oleh mereka yang memerlukan.

\section{B. SARAN}

1. Perlu dilakukan sosialisasi lebih lanjut oleh pemerintah pusat maupun pemerintah daerah terhadap pengoperasian sistem oss.go.id, sehingga mempermudah swasta, civil society, atau pelaku usaha untuk mengoperasikan sistem oss.go.id tersebut sehingga mampu meminimalisir kendala-kendala dalam mendapatkan Nomor Induk Berusaha.

2. Pemerintah Pusat maupun pemerintah daerah harus lebih responsif terhadap kendala-kendala yang dihadapi para swasta, civil society, atau pelaku usaha khususnya dalam pengoperasian sistem oss.go.id tersebut, sehingga pelayanan kepada publik lebih profesional, efektif, efisien dan ekonomis sehingga lebih mudah tercapainya tata kelola pemerintahan yang baik atau Good Governance. 


\section{DAFTAR PUSTAKA}

Nurcholis, Hanif. 2005. Teori dan Praktik Pemerintahan dan Otonomi Daerah.

Grasindo, Jakarta.

Sarundajang. 2002. Arus Balik Kekuasaan Pusat ke Daerah.

Pustaka Sinar Harapan, Jakarta.

Sumarto, Hetifah. 2004. Inovasi, Partisipasi dan Good Governance.

Yayasan Obor Indonesia, Jakarta.

Widodo, Joko. 2001. Good Governance Telaah Dari Dimensi Akuntabilitas dan Kontrol Birokrasi.

Insan Cendekia, Surabaya. 